\title{
Market Efficiency during the Mexican Banks' Privatization Announcement
}

\author{
Roberto J. Santillán-Salgado \\ Finance Department, EGADE Business School-Tecnológico de Monterrey, Monterrey, México \\ Email: Roberto.santillan@itesm.mx
}

Received 6 January 2015; accepted 16 January 2015; published 23 January 2015

Copyright (C) 2015 by author and Scientific Research Publishing Inc.

This work is licensed under the Creative Commons Attribution International License (CC BY). http://creativecommons.org/licenses/by/4.0/

(c) (7) Open Access

\begin{abstract}
During the last years of the decade of the 1980s, the Mexican government reduced its participation as an owner of productive facilities. After privatizing the national railway system, airlines, mining companies, etc., in 1990 it was time to fully privatize the banking industry. Banks had been expropriated eight years before, in September, 1982. However, between 1987 and 1990, fifteen state-owned banks had issued small amounts of stock to the market. So, on May 2nd of 1990, when President Carlos Salinas publicly announced that all government owned banks would soon be fully privatized, several commercial banks were already partially publicly traded. In retrospective, the full-privatization announcement represents a privileged opportunity to test the efficiency of the Mexican stock market at that time. Using Event Study Methodology, this work analyzes how significant was the response of the publicly traded banks' stock price to the full privatization announcement, and quantifies its wealth-creation effects.
\end{abstract}

\section{Keywords}

Privatization of State Owned Enterprises, Capital Market Efficiency in Emerging Markets, Mexico's Banks Privatization

\section{Introduction}

Privatization of State Owned Enterprises (SOEs) gained relevance during the last two decades of the $20^{\text {th }}$ Century. During that period, there were numerous privatization initiatives in both developed and emerging countries. Comprehensive privatization programs confirmed that the private sector was better prepared to operate productive activities successfully in free-market economies ${ }^{1}$.

\footnotetext{
${ }^{1}$ Perotti (1991), for example, discusses that under public ownership governments retain unconditional control over the use of assets. That discretionary power is costly because it encourages rent-seeking behavior by firm insiders, who represent a more coordinated interest group than dispersed taxpayers. In contrast, private owners have both, the incentive and the ability to commit their efforts in pursue of efficient management.
} 
Different authors have reported evidence that State Owned Enterprises (SOEs) underperform private sector firms in terms of profitability, growth and several other measures, giving additional support to privatization programs. Also, ex-post privatization performance measures reports support privatization programs, as has been extensively documented in numerous studies [1]-[5]. Privatization also reduces government intervention in the economy, and the drain of public resources allocated to inefficiently run SOEs [3] [6] [7].

A group of studies on privatization have been centered their attention on the stock price performance of privatized firms, including IPO's shares and their long-run aftermarket performance for both emerging and developed markets. Most of them report significant short-run positive returns, but disappointing long-term performance, opening a whole new field of interest [8]-[11].

This paper takes a different approach to the subject by focusing on the privatization announcement of the Mexican banking sector, which represents an exceptional opportunity to study the efficiency of the Mexican Stock Exchange in what regards the speed and precision with which the news were priced by the stock market. While the size of the sample is small due to the reduced number of privatized entities that existed at that moment $^{2}$, and does not support more general conclusions, the inclusion of institutional and economic context information provides additional elements to interpret the observed reaction of Mexican banks' stock prices.

Many empirical studies have tested the "efficiency" with which financial markets incorporate relevant information into securities prices and have reported abundant evidence that support sit, except for some puzzling but minor "market anomalies"3 . So, the interest of research on the Efficient Markets Hypothesis (EMH) ${ }^{4}$ shifted towards the measurement of the speed and magnitude of the response to identifiable events of financial assets prices, as well as to document market anomalies. The Emerging Financial Markets (EFM's) literature has also produced a number of studies on the same subject, frequently populated with comments about their microstructure, and some other special characteristics that make them less Efficient than more developed countries' markets, and often times contaminated by intense volatility episodes. Some other characteristics of EFM's include the infrequent trading that affects a significant proportion of publicly traded stocks, and the fact they are often times considered "incomplete", in the sense that not many payoff profiles may be constructed with derivatives contracts, because these are almost non-existing [12].

While previous studies focused on a diversity of descriptive and comparative aspects, few give particular attention to the informational efficiency of EFM's. In particular, a somewhat neglected approach has been the evaluation of the impact of relevant information releases on stock prices behavior [13]. It can be contended that such an approach is of great academic interest and that it also has, besides other important implications, a practical relevance for international portfolio managers who diversify the structure of their portfolios holdings with EFM's assets.

Our study presents a series of tests on the efficiency of the Mexican Stock Exchange through the analysis of how publicly traded commercial banks' stocks responded to the full-privatization announcement. In particular, the presence of abnormal returns during the privatization announcement date and surrounding window is analyzed with the Event Study Methodology approach.

Event Study Methodology implicitly tests for the presence of abnormal returns associated with specific informational releases. Screening the magnitude and behavior of the abnormal returns of Mexican banks' stock prices during an event window surrounding the privatization announcement offers interesting insights on the degree (or form) of efficiency at the Mexican Stock Exchange ${ }^{5}$. Additionally, a measure of the absolute magnitude of the returns generated during the announcement event window provides insights into the wealth creation (destruction) impact that relevant information releases can have in a representative Emerging Markets context.

\section{Mexican Banks Privatization}

Only three years after the Mexican government expropriation of commercial banks in 1985, an initial step was taken towards their re-privatization with the announcement that a non-controlling proportion of the banks' capi-

\footnotetext{
${ }^{2}$ The number of government owned banks that were publicly traded at the time of the "full-privatization" announcement was only fifteen. ${ }^{3}$ For example, the "January Effect”, or the "Weekend Effect” (Tinic and West, 1984; Smirlock and Starks, 1986; French, 1980).

${ }^{4}$ Different forms or "degrees" of market efficiency can be observed, depending on the nature of the information that stock prices incorporate. See, for example, [14]-[17].

${ }^{5}$ To our knowledge, by the time of the Mexican Banks' privatization, only [13] had attempted to test the efficiency of the Mexican Stock Exchange. However, [13] centered his attention on the "weak" form of the EMH (although the author does not explicitly say it). Another important difference is that [13]'s sample includes a different set of stocks and covers an earlier time period than this study.
} 
tal was to return to private hands via the stock market. The implementation of the decision occurred during the first semester of 1987, when thirteen out of eighteen existing commercial banks made Initial public offerings (IPO's) in the Mexican Stock Exchange (MSE). The percentage of equity issued varied from one bank to another, but in no case was it greater than 33\%. During the first months of 1990, two more banks made their IPOs. At first, issuing stock of previously privatized banks was used as a test to measure the interest of the investment public to participate as stockholders of Mexican banks. In view of the success achieved, the government finally decided it was possible to re-privatize the whole banking industry. By the time of the privatization announcement, May 2, 1990, there were fifteen publicly traded banks in the Mexican Stock Exchange. As illustrated in Table 1, the dates of the IPOs for 15 bank stocks ran from February 9, 1987, through February 10, 1990.

The full-privatization official announcement was made during the first hours of trading in the morning hours of May the 2nd, 1990. Banks' stocks were already among the most actively traded in the MSE, and had generated very significant returns to investors during recent years. At the moment of the announcement, an average proportion of $29 \%$ of the outstanding stock of fifteen commercial banks was publicly traded in the MSE.

The privatization announcement was taken very optimistically by the MSE participants, where bank stocks traded frantically during that day, overreacting to the imminent privatization of the banking institutions.

The banks privatization process concluded in a little more than one year (from June 10, 1991 to July 4, 1992). During that period eighteen commercial banks' controlling interest (an average of $66.7 \%$ of outstanding stock) was privatized. The Mexican government received \$37856.44 million, equivalent to over US\$12 billion, making that process, by the magnitude of financial resources involved, the most important privatization in Mexico to that date.

\section{The Methodological Aspects}

In this section, we present the steps followed to measure and evaluate the efficiency of the MSE during the privatization announcement period. In the first subsection, we present the database; next, we discuss the Market Model, the theoretical construct used to test the MSE efficiency; next, we refer to the Thin Trading problem that was present in several of the Mexican banks' stocks, as well as the corrections that were deemed necessary.

Table 1. Dates of initial public offerings for 15 bank stocks traded in the Mexican Stock Exchange by the date of the privatization announcement (May $\left.2^{\text {nd }}, 1990\right)$.

\begin{tabular}{ccc}
\hline Larger Banks & First Public Offering \\
\hline Banamex & $2-9-87$ \\
Bancomer & $2-9-87$ \\
Comermex & $5-18-87$ \\
Serfin & $3-23-87$ \\
Smaller Banks & \\
Atlantico & $5-20-87$ \\
Bancen & $4-14-87$ \\
Banoriente & $5-11-87$ \\
Banoro & $6-3-87$ \\
Banorte & $5-14-87$ \\
Confia & $4-20-87$ \\
Cremi & $4-22-87$ \\
Internacional & $4-22-87$ \\
Mercantil & $3-14-90$ \\
Promex & $5-18-87$ \\
Somex & $2-10-90$ \\
\hline
\end{tabular}

Source: newspapers of the period. 


\subsection{The Database}

Bank stock prices and volume traded series used in this study were obtained from the Investment Banking Division of the Banamex-Accival Financial Group. The database consisted of daily closing adjusted prices ${ }^{6}$ from February 6, $1987^{7}$, when the first IPO’s took place, through the end of May, 1990.Two different market indexes were utilized to estimate expected (and abnormal) returns: the IBMV (Indice de la Bolsa Mexicana de Valores) and the Banamex $-30^{8}$. The IBMV is a value weighted index based on a dynamic sample of stocks, revised every other month. Stocks in the portfolio are chosen on the basis of high liquidity, proportion of publicly traded equity and volatility. The weight assigned to an individual stock in the IBMV sample depends on its relative trading value, with respect to the whole portfolio. The IBMV time series for the period was obtained from a magnetic file commercialized by the BolsaMexicana de Valores (BMV).

The Banamex-30 index is an equally weighted average of the returns for the stocks contained in a fixed sample. The size of the sample, as implied by its name, is thirty stocks. This index's series was also obtained from the Banamex-Accival Group.

\subsection{The Market Model}

Although theoretical Asset Pricing Models (like the CAPM, for example) suggest the use of a value weighted index to estimate expected returns, studies based on simulation results, e.g. [18], found that an equally weighted index is more likely to detect abnormal security returns: "returns on randomly selected securities are on average more highly correlated with the equally weighted index than the value weighted index.”

The banking sector is weighted in the sample of stocks included in the Banamex-30 index representing $26.7 \%$ of the total sample. This fact could represent a potential problem of contemporaneous correlation between the stochastic explanatory variable, and the model's residuals, thus resulting in a biased estimation of the parameters. To control for this type of potential estimation errors, both the IBMV and the Banamex-30 indexes were simultaneously contrasted, but no differences in the general conclusions were found.

\subsection{The Thin Trading Problem and the Corrections That Were Required}

Like in most EFMs, the Mexican stock market is affected by low frequency trading. In this paper, the term "thin trading” is used to refer to repeatedly missing daily closing quotations because no trading took place during a given session.

Due to the fact that several banks' stocks presented a thin trading problem during the period of observations used to estimate the Market Model, we built a Thin Trading Index (TTI) to measure trading frequency among stocks by dividing the number of days in which a stock was not traded by the total number of potential trading days. The evidence (reported in Table 2) was clearly supportive of the presence of a serious problem of thin trading for individual stocks. For the period going from the IPO's of each bank to April 30, 1990, only four stocks had a TTI with values of less than 1\%, and sometimes the index was very high (i.e., 66.21\% for Banorie 51.09\% for Promex, and 46.53\% for Confia, respectively). Table 2 presents the Thin Trading Index for the thirteen banks that were publicly traded, from 1987 through May 2, 1990. The number of trading days was counted as the number of days that the market was open, from the date on which the bank stock's initial public offering up to May 2, 1990 (the day of the privatization announcement. The Thin Trading Index was then obtained as the quotient of the number of days of trading that a given stock was not traded divided by the total number of potential trading days.

Alternative approaches were considered to overcome this problem. For example, one possibility could have been estimating the Market Model with monthly data, to eliminate non-trading observations from the sample; a second alternative could have been to select among different adjustment techniques that have been proposed in the literature to eliminate the potential distortion effect of low trading frequency on the Market Model parameters estimation.

When monthly observations were used, measures of goodness-of-fit were highly satisfactory, and the distribution of the regression residuals was closer to normal than was the case with daily observations. However, ba-

\footnotetext{
${ }^{6}$ The Market Model's parameter estimation for individual stocks (as well as for portfolios) was based on the time series data of banks' stocks closing daily prices adjusted for splits, dividends and subscription rights plus the two market indexes closing daily values.

${ }^{7}$ The first two IPO’s (Banamex and Bancomer) were launched on February 6, 1987.

${ }^{8}$ The Banamex-30 index is calculated and published by the Investment Banking Division of the Banamex-Accival Financial Group.
} 
Table 2. Thin Trading Index from the IPO date to the event date (May 2, 1990).

\begin{tabular}{cccc}
\hline Bank & Number of Trading Days & Number of Not Traded Days & Thin Trading Index \\
\hline Atlantico & 731 & 291 & $31.80 \%$ \\
Bancomer & 799 & 2 & $0.25 \%$ \\
Banamex & 799 & 1 & $0.13 \%$ \\
Bancentro & 753 & 170 & $22.58 \%$ \\
Banoriente & 737 & 491 & $66.21 \%$ \\
Banoro & 723 & 273 & $37.75 \%$ \\
Banorte & 734 & 93 & $12.67 \%$ \\
Comermex & 732 & 25 & $3.42 \%$ \\
Confía & 750 & 349 & $46.53 \%$ \\
Cremi & 750 & 228 & $30.40 \%$ \\
Internacional & 749 & 13 & $1.74 \%$ \\
Promex & 732 & 374 & $51.09 \%$ \\
Serfin & 769 & 14 & $1.82 \%$ \\
Average & 751 & 178 & $23.57 \%$ \\
\hline
\end{tabular}

Source: our calculations were based on data obtained from the archives of the Mexican Stock Exchange (Bolsa Mexicana de Valores).

sic disadvantages of this model should be noted: a) the estimation period with 50 monthly observations included a sub-period of high-inflation in which there was a highly speculative stock market boom, followed by a crash (during 1987-1988); b) it also included a second sub-period, with rapidly declining inflation, fixed currency exchange rates, atypically high positive real interest rates and a lateral stock market (during 1989-1990). Testing for structural changes in the parameters of the estimated model was an obvious requirement, given the substantially different macroeconomic conditions that prevailed in each sub-period. As could had been expected, a Chao test rejected the hypothesis of stability of the regression parameters for the two sub-periods (monthly regressions and residuals parameters' analysis and tests are not included in this paper).

Another important drawback of using monthly observations is the fact that measurement of the information impact on prices becomes more imprecise and may be distorted by other concurrent influences. [19] emphasize the importance of establishing the precise event date. Moreover, they indicate that “...tests which incorporate residuals over longer periods are less powerful in detecting abnormal performance than tests specific to the day of announcement.” In order to overcome such limitations and considering the event moment was known we used regressions of daily portfolio returns against the market index returns to test for abnormal returns.

The final choice of estimation period was for 120 observations, searching for a balance between the number of observations that suffices to incorporate the relevant structural characteristics of the "true" model into the "estimated" model and the risk of estimating statistically unstable parameters (which are, maybe, reflecting structural changes in the "true" model), as a result of an excessively long estimation period.

The official banking system privatization announcement took place only a few weeks after the IPO's of the stock of Multibanco Mercantil de Mexico and Banco Mexicano Somex in the Mexican Stock Exchange, allowing very few market observations before the event date. Thus, these two banks had to be excluded from the Market Model estimation.

Not much agreement exists on how to adjust for the potential distortions caused by low-frequency of trading in the estimation of the Market Model parameters. Different authors acknowledge several attempts to develop thin trading adjustment techniques. For example, [20] reported having tested the adjustment techniques proposed by [21] and [22], among other authors. Their findings were that these techniques reduce only a slight proportion of the bias caused by thin trading in estimated Betas.

On the contrary, [23] found that the bias adjustment methodology of [21] seems to effectively reduce the bias 
in OLS estimates of Beta. [24] also compare the infrequent trading adjustment methods of both, [21] and [22], and demonstrate that the [22]'s technique is not correctly specified, so the former technique is recommended.

In this study, the potential bias resulting from low trading frequency in the estimated parameters was corrected by using [21]'s method, which requires running three different regressions on each stock's returns against the market index returns series: one with a lagged observation, one with a contemporaneous observation and one with a leading observation for the market index, combining them as follows:

$$
\beta_{S W}=\frac{b_{n}^{-}+b_{n}^{0}+b_{n}^{+}}{1+2 \rho_{M}}
$$

where, $\rho_{M}=\frac{\sigma_{R_{M t}, R_{M t-1}}}{\sigma_{R_{M t}} \sigma_{R_{M t-1}}}$, and $\alpha_{S W}=\frac{1}{T-2} \sum_{T=2}^{T-1} R_{n t}-\frac{1}{T-2} \beta_{S W} \sum_{T=2}^{T-1} R_{M t}$

$\beta_{S W}=$ calculated value for market model regression line slope.

$\alpha_{S W}=$ calculated value for market model regression line intercept.

$b_{n}^{-}=$calculated regression line slope for lagged market return.

$b_{n}^{0}=$ calculated regression line slope for market return.

$b_{n}^{+}=$calculated regression line slope for advanced market return.

$\rho_{M}=$ correlation between normal and 1 day lagged series of market returns.

$R_{M t}=$ market return at time $t$.

$R_{M t-1}=$ market return at time $t-1$.

$\sigma_{R_{M t}, R_{M t-1}}=$ covariance between $R_{M t}$ and $R_{M t-1}$.

$\sigma_{R_{M t}}=$ standard deviation of $R_{M t}$.

$\sigma_{R_{M t-1}}=$ standard deviation of $R_{M t-1}$.

[23] reported that the choice of the variance estimator to be used in Event Studies hypothesis testing is of some concern, since it can affect both the specification and the power of the tests. Since the sample includes only bank stocks, and the event date of interest was the same for all the banks, the likeliness of observing both serial and cross correlation among stocks' prices was high. In order to account for these problems, [25]'s method to overcome a potential variance estimation bias in the presence of serial and cross correlation was followed because both statistical problems were present in the database.

Abnormal returns were estimated by first aggregating the raw returns of individual stocks into one of the three different portfolios, then estimating the Market Model parameters for each portfolio, and finally calculating the deviation between observed and expected returns.

$$
A R p t=R p t-\hat{\alpha}_{p}-\hat{\beta}_{p} R m t
$$

And the estimator used to standardize abnormal returns was:

$$
\sigma^{2} p=\sum \frac{(R p i-E(R p))^{2}}{(t-2)}
$$

Given that the standard deviation of abnormal returns can be interpreted as an "average" value of the dispersion of the data, an adjustment that incorporates the divergence of the estimated values as the distance from the average value of the regressor variable increases was performed, as follows:

$$
\sigma(f p t)=\sigma_{p}\left[1+\frac{1}{T}+\frac{(R m t-\overline{R m})^{2}}{\sum_{j=1}^{T}(R m j-\bar{R} m)^{2}}\right]^{1 / 2}
$$

The standardized abnormal return to be statistically tested was defined as:

$$
S A R p t=A R p t / \sigma(f p t)
$$


which is distributed like a " $t$ " statistic with $t-1$ degrees of freedom.

Since the stock's returns are measured as continuously compounded, cumulative abnormal returns from 1 to $U$ are simply the sum of the single period returns:

$$
C A R p=\sum_{t=1}^{U} A R p t
$$

The formula for the variance estimator used, adjusted for inter-temporal correlation is:

$$
\sigma_{f p c}^{2}=U \sigma_{p}^{2}\left[1+\frac{U}{T}+\frac{U\left(\frac{C R m}{U}-\overline{R m}\right)^{2}}{\sum_{j=1}^{T}(R m j-\bar{R} m)^{2}}\right]
$$

where:

$\sigma_{f p c}^{2}=C A R$ variance that takes into account autocorrelation.

$U=$ Accumulation period.

$T=$ Estimation period of length $T$.

$\sigma_{p}^{2}=$ Forecast error variance for portfolio $p$.

$C R m=$ Cumulative return of $R m$, during the peiiod $U$.

$\overline{R m}=$ Average market return during estimation period.

Finally, the standardized cumulative abnormal return used to test the hypothesis of abnormal returns presence was:

$$
S C A R p=C A R p / s_{f p c}
$$

\subsection{Abnormal Returns Estimation}

According to the Event Study Methodology, based on the Capital Asset Pricing Model, market traded assets' returns must correspond to their systematic risk. The presence of abnormal returns during the event window surrounding May 2, 1990 was tested with four different models. The first two models consisted in running OLS regressions for 120 daily bank stocks returns against the market index returns, from -150 through -30 , with respect to the event date. The last two, incorporate the Scholes and Williams' adjustment method to correct for the potential bias caused by thin trading.

Cross-correlation was likely to be present among bank stocks' returns during the estimation period. When such is the case, according to [25], Event Study literature reports a common procedure developed by [26] and [27] that consists in combining all stocks whose event window includes a particular day, in a portfolio; then, estimating the Market Model and, finally, estimating the portfolio's abnormal returns. Testing for the presence of abnormal returns in this study follows that methodology. Three different portfolios were, thus, integrated:

- Portfolio 1: Including the stocks of the four largest banks .

- Portfolio 2: Including nine ${ }^{10}$, second-tier banks ${ }^{11}$. Notwithstanding their smaller operative size, this group contains several nation-wide branched banks.

- Portfolio 3: Including the thirteen banks.

The first two portfolios evaluated the response of the largest bank stock and the second-tier banks returns, separately. The third was used to contrast the average response with each one of the two subgroups.

\subsection{Hypothesis Tests and Results}

Hypotheses tested to detect abnormal returns that can be attributed to the May 2, 1990 announcement were:

\footnotetext{
${ }^{9}$ Banamex, Bancomer, Serfin and Comermex.

${ }^{10}$ The number of second-tier banks whose stocks were publicly traded on the privatization announcement date was eleven, but two of them (Somex and MultibancoMercantil de Mexico) had made IPO's only a few weeks before the event, and insufficient market price observations were available. For that reason they were not included in the models' estimation.

${ }^{11}$ Banpais, Cremi, Confia, Banoriente, Bancreser, B.C.H., Atlantico, Promex, Banoro, Internacional and Bancen.
} 
Ho1: "There was no abnormal return present on bank stocks on the official privatization-related information release trading day."

Ha1: "There was, in effect, a significant abnormal return as result of the official privatization-related information release".

Rejection of the null hypothesis would mean that a statistically significant wealth effect resulted during the event day, and, thus, is congruent with the semi-strong form of the EMH.

Ho2: “There was no abnormal return on the next day of the Official Information Release".

Ha2: "There was, in effect, a significant abnormal return on the next day of the Official Information Release".

According to the EMH stocks prices should have incorporated the privatization announcement content during the first trading session. The wealth effect that was generated by the announcement was so strong that one trading session was not sufficient for bank stock prices to fully adjust. According to the semi-strong form of the EMH, abnormal returns should not had been significantly different from zero, during the next day's trading session, in the absence of still another new piece of relevant information. A rejection of the null hypothesis offers evidence that investors' behavior was influenced by the previous day's announcement and the stock market's response to the announcement. In other words, there was an inertial effect of optimism.

Ho3: "There were not cumulative abnormal returns present during the trading days previous to the official privatization announcement".

Ha3: "There were, in effect, significant cumulative abnormal returns before the official privatization announcement".

Abnormal returns were studied for individual stocks and for the different portfolios, and a repeated regularity was observed in their pattern. In all cases there was a positive cumulative abnormal return during the first fifteen days of the thirty-day period previous to the event day, then curving down (negative cumulative abnormal returns) in the last fifteen days. For that reason, this hypothesis was tested over alternative event windows, as described below:

- 1st. event window, from day $\mathbf{- 3 0}$ to day 0: A rejection of the null hypothesis can be interpreted as evidence that the existence of a strong-form efficiency in the Mexican market at that time is questionable, because it would amount to stating that investors could make excess returns by trading on insider information during that period. The strong-form of the EMH assumes that insider-trading on privileged information produces all the necessary price adjustments to reflect any relevant modification of the fundamental situation and returns perspectives of a company, without significantly deviating the stock's returns away from the expected returns. Cumulative abnormal returns that significantly differ from zero could represent statistical evidence of trading activity based on information that was not publicly available. This test was further separated in two sub-periods. Given the opposite trends observed on the graphical representations of abnormal returns through the whole 30-day period, some interesting conclusions were obtained from the sub-periods tests.

- 2nd. event window, from day $-\mathbf{3 0}$ to day -16: For this event window, rejection of the null hypothesis is interpreted as statistical evidence that cumulative abnormal returns were present. It can be theorized that if a group of participants were aware of the privatization announcement before the rest of the market and, thus, were able to anticipate the likely impact that the announcement was to have on bank stocks prices, their trading activities could have produced statistically significant abnormal returns through an increased demand.

- 3rd. event window, from day $\mathbf{- 1 5}$ trough the event day (day 0): In case of rejecting the null hypothesis, a tentative explanation could be that after the accumulation period observed from days -30 through -16 , the reduced group of insiders, either decided to stop trading to avoid attracting too much attention from other market participants, or had already exhausted their savings in building-up inventories of banks stocks. Market participants, who were not convinced that the historically high observed quotations for the bank's stocks were justified, given the publicly available fundamental information, didn't find a motive to maintain high demand levels resulting in the days -15 to -1 days declining cumulative abnormal returns trend.

Ho4: The volume of bank stocks traded during the event windows analyzed in Hypothesis test number 3 were not significantly different from the volume observed in the day -60 to day -30 period.

Ha4: There was a significant difference in the mean volume of stocks traded during the event windows of Hypothesis test number 3 , when compared to the day $\mathbf{- 6 0}$ to day -30 period.

In this case, a rejection of the null hypothesis would support an argument for the presence of speculative ac- 
tivity. Estimation of abnormal returns was performed with separate OLS regressions between each portfolio and both market indexes, adjusting the estimated parameters with [21]'s technique. Abnormal returns were standardized to measure their statistical significance with standard deviations estimated for the one, two, fifteen and thirty days event windows, following [25]. The regression models had an average adjusted $R^{2}$ of 0.65310 when the Banamex-30 index was used as regressor, while for the IBMV the average was 0.46754 . The "F" tests for all the regressions were significant at less than $0.0001 \%$ level (Table 3 ).

With respect to the assumption of normality in the distribution of the returns observations, different studies find daily stock prices frequently having more observations both in their central portions and in their extreme tails than what is expected from normal distributions. In addition, [23] confirm that the non-normal distribution also holds for daily excess returns. Departures from normality are reported less pronounced for cross-sectional mean excess returns than for individual security excess returns. But, as earlier mentioned, their simulation results confirm that the non-normality problem does not significantly modify the significance of abnormal returns' tests results. [19] also present results that support the accuracy of the T-tests to detect the presence of abnormal returns, although distributions of daily returns residuals are clearly non-normal.

To test for the normality of the abnormal returns' (residual's) distribution, the kurtosis, skewness and studentized range were calculated. Abnormal returns were found to have a more peaked distribution than could be expected for a normal distribution. Also, estimated kurtosis was larger than three standard deviations above the normal "zero" mean. The different regression estimated models' residual values fell, in all cases, within the range of one standard deviation above of the mean. Studentized ranges produced results that are observed in a normal distribution with a probability of less than $5 \%$ (Table 4).

\subsection{Results' Interpretation}

The Presidential initiative to privatize Mexican banks was announced in the early morning of Wednesday, May 2, 1990. The news rapidly spread out and, once that day's trading session opened, a highly positive impact was observed in the price of the banks' stock prices, as well as in those of most other stocks. The daily market's return was $6.2 \%$ according to the Banamex-30 index or $4.5 \%$, if measured with the IBMV. When compared to the average daily return of both indexes during the previous 30 trading days, of $0.6 \%$ and $0.4 \%$, respectively, that day's returns were nothing less than extraordinary. Bank stocks were the most actively traded that day, and their returns were still more extraordinary. The average return for the fifteen publicly traded banks' stock was $11.17 \%$ and the next day's returns represented an additional $8.44 \%$.

In order to make a technical evaluation of the significance of the banks' stock prices observed returns with respect to the Market Model's estimated expected returns, we made an event study for the day of the privatization announcement and for other event windows. Two-tailed tests were used and, as was expected, the null hypothesis of "no abnormal returns" was comfortably rejected at a $5 \%$ significance level.

Table 3. Regression parameters for bank stock portfolio returns with 120 observations from -150 to -30 with respect to May 2, 1990. This table presents the parameters from regressions for three portfolios of bank stocks: the four larger banks, the nine smaller banks, and all the banks against a market index. Two different market proxies were employed as the independent variable: the Banamex-30 index and the IBMV.

\begin{tabular}{cccccccc}
\hline & Intercept & P-Value & Beta & $\mathbf{R}^{2}$ & Adjusted $\mathbf{R}^{2}$ & F-Statistic & Sig. of $\mathbf{F}$ \\
\hline Large Banks & & & & & & & \\
\hline BNMX-30 & 0.0027 & 0.0166 & 1.3036 & 0.7117 & 0.7093 & 291.2975 & 0.0000 \\
IBMV & 0.0040 & 0.0041 & 1.3166 & 0.5649 & 0.5612 & 153.2183 & 0.0000 \\
Smaller Banks & & & & & & \\
BNMX-30 & 0.0054 & 0.0000 & 0.9223 & 0.5533 & 0.5495 & 146.1519 & 0.0000 \\
IBMV & 0.0064 & 0.0000 & 0.8408 & 0.3578 & 0.3524 & 65.7502 & 0.0000 \\
All Banks & & & & & & & 0.000 \\
BNMX-30 & 0.0046 & 0.0000 & 1.0396 & 0.7030 & 0.7005 & 279.3656 & 0.0000 \\
IBMV & 0.0057 & 0.0000 & 0.9872 & 0.4933 & 0.4890 & 114.8827 & 0.0000 \\
\hline
\end{tabular}

Source: own calculations. 
Table 4. Abnormal returns following the Mexican banks privatization announcement. The following table shows the abnormal returns recorded on the day of the announcement that Mexican banks would be privatized (May 2, 1990) and the following day (May 3, 1990). The abnormal returns are estimated as in Equation (1) for three portfolios of bank stocks: the four larger banks, the nine smaller banks, and all the banks. Two different proxies were used for the market index: the Banamex30 index and the IBMV.

\begin{tabular}{|c|c|c|}
\hline & May 2 & May 3 \\
\hline \multicolumn{3}{|l|}{ Larger Stocks } \\
\hline $\begin{array}{c}\text { BNMX-30 } \\
\text { Abnormal Return } \\
\text { Standard Error } \\
\text { Significance Level }\end{array}$ & $\begin{array}{c}0.0686 \\
(0.0130) \\
0.001\end{array}$ & $\begin{array}{c}0.0368 \\
(0.0126) \\
0.004\end{array}$ \\
\hline $\begin{array}{c}\text { IBMV } \\
\text { Abnormal Return } \\
\text { Standard Error } \\
\text { Significance Level }\end{array}$ & $\begin{array}{c}0.0861 \\
(0.0156) \\
0.001\end{array}$ & $\begin{array}{c}0.0543 \\
(0.0151) \\
0.001\end{array}$ \\
\hline \multicolumn{3}{|l|}{ Smaller Stocks } \\
\hline $\begin{array}{c}\text { BNMX-30 } \\
\text { Abnormal Return } \\
\text { Standard Error } \\
\text { Significance Level }\end{array}$ & $\begin{array}{c}0.0257 \\
(0.0131) \\
0.049\end{array}$ & $\begin{array}{c}0.0288 \\
(0.0126) \\
0.027\end{array}$ \\
\hline $\begin{array}{c}\text { IBMV } \\
\text { Abnormal Return } \\
\text { Standard Error } \\
\text { Significance Level }\end{array}$ & $\begin{array}{c}0.0435 \\
(0.0154) \\
0.005\end{array}$ & $\begin{array}{c}0.0456 \\
(0.0150) \\
0.003\end{array}$ \\
\hline \multicolumn{3}{|l|}{ All Bank Stocks } \\
\hline $\begin{array}{c}\text { BNMX-30 } \\
\text { Abnormal Return } \\
\text { Standard Error } \\
\text { Significance Level }\end{array}$ & $\begin{array}{c}0.0389 \\
(0.0106) \\
0.001\end{array}$ & $\begin{array}{c}0.0313 \\
(0.0102) \\
0.003\end{array}$ \\
\hline $\begin{array}{c}\text { IBMV } \\
\text { Abnormal Return } \\
\text { Standard Error } \\
\text { Significance Level }\end{array}$ & $\begin{array}{c}0.0566 \\
(0.0136) \\
0.001\end{array}$ & $\begin{array}{c}0.0482 \\
(0.0132) \\
0.001\end{array}$ \\
\hline
\end{tabular}

Source: own calculations based on the Market Model and publicly available market data.

The different hypotheses tests results were as follows:

- Ho1: was rejected at less than 1\% significance level, except for the Portfolio 2/Banamex-30 model, where only a 5\% significance level rejection was possible (see Table 4). In general terms, this hypothesis test results were consistent with the proposition that the official announcements of the Mexican banks' privatization had a significant impact on bank stock prices. The response of bank stocks to the privatization announcement leaves no doubt to the presence of a semi-strong form efficiency in the Mexican Stock Exchange during that trading day. Practically all the hypotheses tested for this event yield the same confirmation of the presence of highly positive abnormal returns (see Table 4). The relative magnitude of price increases for bank stocks on that day was many times larger than the average return during the previous months in all cases, so individual absolute differences are not relevant.

- Ho2: On the next day of the privatization announcement, the market again showed a strong bullish response. Bank stocks returns were specially notorious, reaching an $8.44 \%$ return in average. The magnitude of the accumulated wealth effect in those two days was, indeed, very large. Calculated abnormal returns were $3.1 \%$ and 4.8\% for the Portfolio 3 Model, with the Banamex-30 index and the IBMV, respectively (see Table 4). Rejection of the null hypothesis at a less than $1 \%$ significance level was straightforward in five of the six models. The only exception, again, corresponded to the Portfolio 2/Banamex-30 model, in which case the null was rejected at a 3\% significance level. Abnormal returns for the day-after of the privatization announcement should not have been significantly different from zero in the absence of another piece of relevant information that justified their presence. An unanimous rejection of the null hypothesis of no abnormal 
returns represents evidence that investors behavior was inertial, certainly influenced by the previous day's stocks prices response to the privatization announcement. It can also be argued information diffusion and investors' response seems to be slower in the Mexican Stock Exchange than what would be expected in more mature markets. But that is not the only possible explanation. The next day's abnormal returns statistical significance may either reflect a delay in response due to the late information awareness, or a very intense revaluation of bank stocks worth. This last possibility gives support to the hypothesis that the Mexican market was, in effect, a semi-strong form inefficient market. The banks privatization announcement was deeply transcendental for investors' expectations regarding the Mexican bank's future earnings potential, but the time needed to assimilate the new circumstances was too long to accept the existence of a semi-strong efficient market. On the day of the privatization announcement, the wealth effect generated represented almost 58 million dollars, while the next day amounted to 40 million dollars. The total cumulative wealth effect during those two days was 97 million dollars. The stocks in Portfolio 1 accounted for $76 \%$ of that amount, and those in Portfolio 2, plus Somex and Mercantil, for the rest (Table 5).

- Ho3 results for the different event windows were as follows:

- From day -30 today 0: Under this event window the null hypothesis was not rejected for any portfolio. Nevertheless, it should be noted that the 30-day cumulative abnormal returns for which the hypotheses tests were not rejected averaged $4.25 \%$, but the average estimated standard deviation was still larger, i.e., 5.5\%, suggesting a highly unstable period.

- From day -30 through day -16: The graphical representations of each portfolios' cumulative abnormal returns, showed a constant pattern in all cases. That pattern suggested a positive trend for the -30 through -16 sub-period and a negative trend for the -15 through -1 sub-period.

The null hypothesis of non-significant cumulative abnormal returns during the -30 through -16 days period was consistently rejected for all the models at a $3 \%$ significance level, thus giving statistical support to the graphical evidence and to the argument that something strange was taking place.

There had been an ongoing public discussion of a possible privatization since the early days of 1990. Consequently, we searched the media in the US (through Nexus-Lexus) and in Mexico (El Financiero, Excelsior, and El Norte) and did not find anticipation of the banks privatization event. Although there was evidently some anticipation of privatization at a later date, the timing of the announcement came as a complete surprise $\mathrm{e}^{12}$. Since we cannot determine how much of the announcement was anticipated, our analysis does not completely capture the wealth effect of the privatization announcement. Because the privatization was partially anticipated by investors, part of the wealth effect was already capitalized in the stock price before the announcement date. Thus, we cannot assume that the reaction found was the total expected wealth effect from the change. Rather we focus on the sign and significance of the abnormal returns and consider the magnitude to be a lower bound.

- From day $\mathbf{- 1 5}$ through day $\mathbf{- 1}$ : This test complements the previous one. Negative cumulative abnormal returns averaged $-8.9 \%$, but when contrasted with their high variability, the hypothesis could not be rejected at a 5\% significance level, except in the case, of the Portfolio3/Banamex-30 model. During this event window, while statistical tests did not indicate that the magnitude of abnormal returns was significantly different from zero, what should not pass disregarded is the fact that cumulative abnormal returns were negative for all portfolios.

Cumulative abnormal returns graphical pattern for the 30 days period previous to the privatization announcement is certainly suggestive. When the period is divided in two subperiods, positive abnormal returns from day -30 to day -16 are highly significant. The second sub-period results are mostly non-significant, except for the Portfolio 3/Banamex -30 model. In this last model's test, negative abnormal returns are significant only at a $5 \%$ level.

A way to confirm the presence of speculative activity in an indirect form during the period of interest is to look at the behavior of trading volume. To confirm if there was a speculative activity that produced the positive cumulative abnormal returns observed during the day -30 to day -16 sub-period, a statistical analysis comparing the average daily volume traded in that sub-period with the average volume traded in the day -60 to day -31 period could prove useful. The analysis was performed with T-tests for the day -30 to day -1 period and the two subperiods described above for each bank stock.

The null hypothesis in this case was that the average volume traded during the periods of interest was not significantly different in a statistical sense from the average volume traded during -60 to day -31 period. The null for the -30 to -1 versus -60 to -31 periods can only be rejected at a $5 \%$ significance level for Somex, and for

\footnotetext{
${ }^{12}$ See, for example, Brown (1990).
} 
Table 5. Wealth effects of the Mexican banks privatization announcement. This table presents the changes in market value of the publicly traded bank stocks on May 2, 1990, the day of the announcement that the banks would be $100 \%$ privatized (a) and on May 3, 1990, the day following the announcement (b). The figures are given for each of the banks individually and for three portfolios of the bank stocks: the four larger banks, the nine smaller banks, and all of the banks combined.

(a)

\begin{tabular}{ccccc}
\hline Bank & Market value of stock traded* & Return on May 2 & In millions of pesos & In millions of US dollars \\
\hline ATLANTICO & 63436.0 & $14.9 \%$ & 9472.9 & 3.4 \\
BANAMEX & 1382280.5 & $14.7 \%$ & 203139.2 & 72.4 \\
BANCEN & 106835.7 & $9.5 \%$ & 10102.6 & 3.6 \\
BANORTE & 196018.8 & $9.9 \%$ & 19478.9 & 6.9 \\
BANCOMER & 1301471.9 & $14.6 \%$ & 190551.2 & 68.0 \\
BANORIENTE & 30180.0 & $0.0 \%$ & 0.0 & 0.0 \\
BANORO & 115914.0 & $14.7 \%$ & 17073.6 & 6.1 \\
COMERMEX & 277734.6 & $14.7 \%$ & 40917.1 & 14.6 \\
CONFIA & 47556.1 & $10.0 \%$ & 4754.1 & 3.7 \\
CREMI & 78568.0 & $11.7 \%$ & 9189.1 & 12.4 \\
INTERNAC. & 218927.9 & $15.9 \%$ & 34842.0 & 2.2 \\
MERCANTIL & 42627.6 & $14.6 \%$ & 6206.0 & 0.0 \\
PROMEX & 124596.7 & $0.0 \%$ & 0.0 & 29.6 \\
SERFIN & 572069.3 & $14.5 \%$ & 82884.8 & 2.5 \\
SOMEX & 74510.1 & $9.4 \%$ & 6968.6 & 184.6 \\
Large banks & 3533556.4 & $14.6 \%$ & 517492.4 & 42.1 \\
Small banks & 1099170.9 & $10.7 \%$ & 118087.7 & 226.7 \\
All banks & 4632727.3 & $13.7 \%$ & 635580.1 & \\
\hline
\end{tabular}

*In millions of pesos on April 30, 1990 (there was not a trading session on May 1, 1990 due to a national holiday).

(b)

\begin{tabular}{ccccccc}
\hline Bank & $\begin{array}{c}\text { Return } \\
\text { on May 3 }\end{array}$ & $\begin{array}{c}\text { In millions } \\
\text { of pesos }\end{array}$ & $\begin{array}{c}\text { In millions } \\
\text { of US dollars }\end{array}$ & $\begin{array}{c}\text { Two-day } \\
\text { cumulative } \\
\text { return }\end{array}$ & $\begin{array}{c}\text { Two-day return } \\
\text { in millions } \\
\text { of pesos }\end{array}$ & $\begin{array}{c}\text { Two-day return } \\
\text { in millions } \\
\text { of US dollars }\end{array}$ \\
\hline ATLANTICO & $3.2 \%$ & 2314.7 & 0.8 & $18.6 \%$ & 11787.6 & 4.2 \\
BANAMEX & $11.0 \%$ & 174929.2 & 62.4 & $27.4 \%$ & 378068.4 & 134.8 \\
BANCEN & $10.0 \%$ & 11702.1 & 4.2 & $20.4 \%$ & 21804.7 & 7.8 \\
BANORTE & $12.5 \%$ & 26960.6 & 9.6 & $23.7 \%$ & 46439.4 & 16.6 \\
BANCOMER & $8.5 \%$ & 127107.8 & 45.3 & $24.4 \%$ & 317659.0 & 113.3 \\
BANORIENTE & $14.3 \%$ & 4325.5 & 1.5 & $14.3 \%$ & 4325.5 & 1.5 \\
BANORO & $9.6 \%$ & 12811.4 & 4.6 & $25.8 \%$ & 29885.0 & 10.7 \\
COMERMEX & $9.2 \%$ & 29178.1 & 10.4 & $25.2 \%$ & 70095.3 & 25.0 \\
CONFIA & $9.9 \%$ & 5194.8 & 1.9 & $20.9 \%$ & 9948.9 & 3.5 \\
CREMI & $7.7 \%$ & 6778.1 & 2.4 & $20.3 \%$ & 15967.1 & 5.7 \\
INTERNAC. & $5.2 \%$ & 13191.0 & 4.7 & $21.9 \%$ & 48033.0 & 17.1 \\
MERCANTIL & $7.5 \%$ & 3641.5 & 1.3 & $23.1 \%$ & 9847.4 & 3.5 \\
PROMEX & $0.0 \%$ & 0.0 & 0.0 & $0.0 \%$ & - & 0.0 \\
SERFIN & $8.5 \%$ & 55464.5 & 19.8 & $24.2 \%$ & 138349.2 & 49.3 \\
SOMEX & $12.6 \%$ & 10240.9 & 3.7 & $23.1 \%$ & 17209.6 & 6.1 \\
Large banks & $10.9 \%$ & 386679.5 & 137.9 & $27.2 \%$ & 904171.9 & 322.5 \\
Small banks & $8.8 \%$ & 97160.5 & 34.7 & $20.5 \%$ & 215248.2 & 76.8 \\
All banks & $10.4 \%$ & 483840.0 & 172.6 & $25.6 \%$ & 1119420.0 & 399.2 \\
\hline
\end{tabular}

Source: own calculations, made with publicly available information. 
Banorte and Bancen at a $10 \%$ significance level. The same hypothesis for the -30 to -16 window was rejected at a $5 \%$ significance level for Atlantico (1\% significance level) Bancen, Bancomer, Internacional and Somex, and at a $10 \%$ significance level for Banamex.

A general result derived from the cumulative abnormal returns analysis is that, for some reason that could tentatively be associated with trading on non-public information, bank stocks prices behaved abnormally during the 30-day event window previous to the banking system privatization announcement.

\section{Conclusions}

The response of the Mexican bank stocks that were publicly traded at the time to the privatization announcement that took place on May $2^{\text {nd }}, 1990$ and the different contemplated windows was abnormally positive in all cases,. Statistically significant residuals (or abnormality of returns), reflect the perception of a significant wealth creation event, so it seems relevant to attempt an explanation. Although the evidence leaves open the possibility that the wealth creation process surrounding the event window occurred because there existed non-public information trading, no conclusive arguments could be found and only some logical inferences can be made.

Regression results to estimate the Market Model's parameters were highly satisfactory in most cases, and the significance of all regression coefficients and the coefficients of determination look well when compared to other empirical studies of the same nature.

As was to be expected, given the composition of the Banamex-30 index, Market Model regressions that used it consistently presented higher coefficients of determination than those that used the IBMV. Notwithstanding, tests results were robust when the models used to calculate abnormal results were estimated with both indexes.

With respect to the normality of the residuals tests, it was posible to reject null that abnormal returns belong to a normal parent distribution, except for a few cases. Consistent with other authors conclusions, estimated abnormal returns for banks stocks during the privatization period follow a right side skewed and more than normally peaked distribution. Also, a higher than normal proportion of the observations falls into the tails of the sample distribution (i.e., one observes a "fat tails" distribution).

Even when the non-normality of abnormal returns presence is unquestionable, hypotheses tests to establish the significance of abnormal returns during event dates support consistent conclusions. Based on other authors' findings, the correctness of calculated test statistics should not be suspect of methodological inadequacy. Nevertheless, the reader should be aware of the characteristics of the database, before attempting a generalization of the results obtained.

A large number of studies have documented the efficiency of the stock markets in the United States and other developed countries. This work's main contribution is to document the fast reaction of the Mexican banks' stock prices to the full-privatization announcement, to analyze the banks' stock price behavior in different time-windows surrounding the May $2^{\text {nd }}, 1990$ event date and quantifying the wealth effect that the privatization announcement had on the market value of Mexican banks' stocks.

\section{References}

[1] Boycjo, M., Schleifer, A. and Vishny, R.W. (1994) Voucher Privatization. Journal of Financial Economics, 35, 249266. http://dx.doi.org/10.1016/0304-405X(94)90006-X

[2] Boardman, A.E. and Vining, A.R. (1989) Ownership and Performance in Competitive Environments: A Comparison of the Performance of Private, Mixed, and State-Owned Enterprises. Journal of Law and Economics, 32, 1-33. http://dx.doi.org/10.1086/467167

[3] Galal, A., Jones, L., Tandon, P. and Vogelsang, I. (1992) Welfare Consequences of Selling Public Enterprises. World Bank, Washington DC.

[4] Megginson, W.L., Nash, R.C. and Van Randenborgh, M. (1994) The Financial and Operating Performance of Newly Privatized Firms: An International Empirical Analysis. Journal of Finance, 49, 403-452. http://dx.doi.org/10.1111/j.1540-6261.1994.tb05147.x

[5] Boubakri, N. and Cosset, J. (1998) The Financial and Operating Performance of Newly, Privatised Firms: Evidence from Developing Countries. Journal of Finance, 53, 1081-1110. http://dx.doi.org/10.1111/0022-1082.00044

[6] Hachette, D. and Lüders, R. (1992) La Privatización en Chile. Centro Internacional para el Desarrollo Económico, Santiago de Chile.

[7] Indacochea, A.(1993) Privatizar la Privatización y Reflexiones sobre el Nuevo Orden Económico Mundial. Esan/Ide, 
Lima.

[8] Aggarwal, R., Leal, R. and Hernandez, L. (1993) The Aftermarket Performance of Initial, Public Offerings in Latin America. Financial Management, 22, 42-53. http://dx.doi.org/10.2307/3665964

[9] Dewenter, K.L. and Malatesta, P.H. (1997) Public Offerings of State-Owned and Privately-Owned Enterprises: An International Comparison. Journal of Finance, 52, 1659-1679. http://dx.doi.org/10.1111/j.1540-6261.1997.tb01125.x

[10] Loughran, T., Ritter, J.R. and Rydqvist, K. (1994) Initial Public Offerings: International Insights. Pacific-Basin Finance Journal, 2, 165-199. http://dx.doi.org/10.1016/0927-538X(94)90016-7

[11] Perotti, E. and Guney, S.E. (1993) The Structure of Privatization Plans. Financial Management, 22, 84-98. http://dx.doi.org/10.2307/3665968

[12] Hakansson, N. (1977) The Superfund Efficient Task towards Efficient Capital Markets in Large and Small Countries. In: Levy and Sarnat, Eds., Financial Decision Making under Uncertainty, Academic Press, Waltham.

[13] Hakim, M. (1992) The Efficiency of the Mexican Stock Market. Garland Press, New York.

[14] Lorie, J.H. and Hamilton, M.T. (1973) The Stock Market, Theories and Evidence. Richard D. Irwin, Homewood.

[15] Dickman, T. and Morse, D. (1986) Efficient Capital Markets and Accounting: A Critical Analysis. 2nd Edition, Prentice Hall, Englewood Cliffs.

[16] Fama, E. (1991) Efficient Capital Markets: II. Journal of Finance, 46, 1575-1617. http://dx.doi.org/10.1111/j.1540-6261.1991.tb04636.x

[17] Elton, E.J. and Gruber, M.J. (1991) Modern Portfolio Theory and Investment Analysis. 4th Edition, John Wiley and Sons, Singapore City.

[18] Brown, S. and Warner, J. (1980) Measuring Security Price Performance. Journal of Financial Economics, 8, $205-258$. http://dx.doi.org/10.1016/0304-405X(80)90002-1

[19] Dyckman, T., Philbrick, D. and Stephan, J. (1984) A Comparison of Event Study Methodologies: A Simulation Approach. Journal of Accounting Research, 22, 1-33.

[20] McInish, T.H. and Wood, R.A. (1986) Adjusting for Beta Bias: An Assessment of Alternate Techniques: A Note. Journal of Finance, 41, 277-286. http://dx.doi.org/10.1111/j.1540-6261.1986.tb04507.x

[21] Scholes, M. and Williams, J. (1977) Estimating Betas from Nonsynchronous Data. Journal of Financial Economics, 5, 309-327. http://dx.doi.org/10.1016/0304-405X(77)90041-1

[22] Dimson, E. (1978) Risk Measurement When Shares Are Subject to Infrequent Trading. Journal of Financial Economics, 9, 197-226.

[23] Brown, S. and Warner, J. (1985) Using Daily Stock Returns: The Case of Event Studies. Journal of Financial Economics, 14, 3-31. http://dx.doi.org/10.1016/0304-405X(85)90042-X

[24] Fowler, D. and Rorke, C. (1983) Risk Measurement When Shares Are Subject to Infrequent Trading: Comment. Journal of Financial Economics, 12, 279-283. http://dx.doi.org/10.1016/0304-405X(83)90039-9

[25] Salinger, M. (1992) Standard Errors in Event Studies. Journal of Financial and Quantitative Analysis, 27, 39-53. http://dx.doi.org/10.2307/2331297

[26] Mandelker, G. (1974) Risk and Return: The Case of Merging Firms. Journal of Financial Economics, 1, 303-335. http://dx.doi.org/10.1016/0304-405X(74)90012-9

[27] Jaffe, J.F. (1974) Special Information and Insider Trading. The Journal of Business, 47, 410-428. http://dx.doi.org/10.1086/295655 
Scientific Research Publishing (SCIRP) is one of the largest Open Access journal publishers. It is currently publishing more than 200 open access, online, peer-reviewed journals covering a wide range of academic disciplines. SCIRP serves the worldwide academic communities and contributes to the progress and application of science with its publication.

Other selected journals from SCIRP are listed as below. Submit your manuscript to us via either submit@scirp.org or Online Submission Portal.
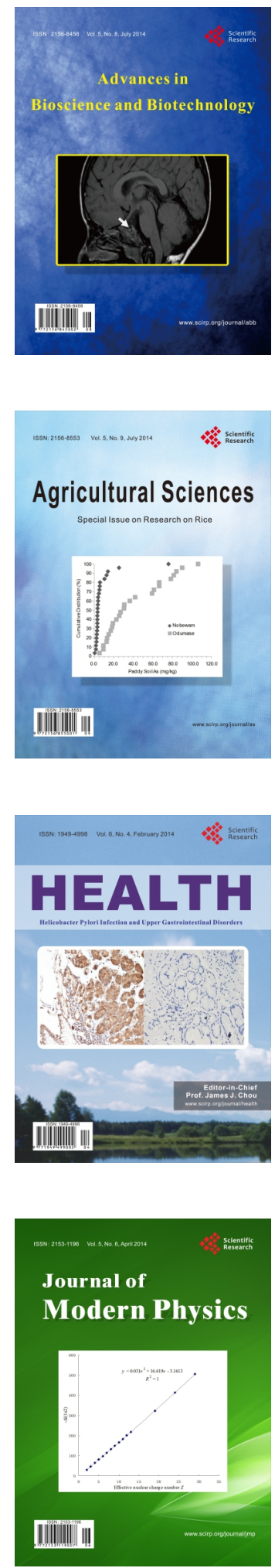
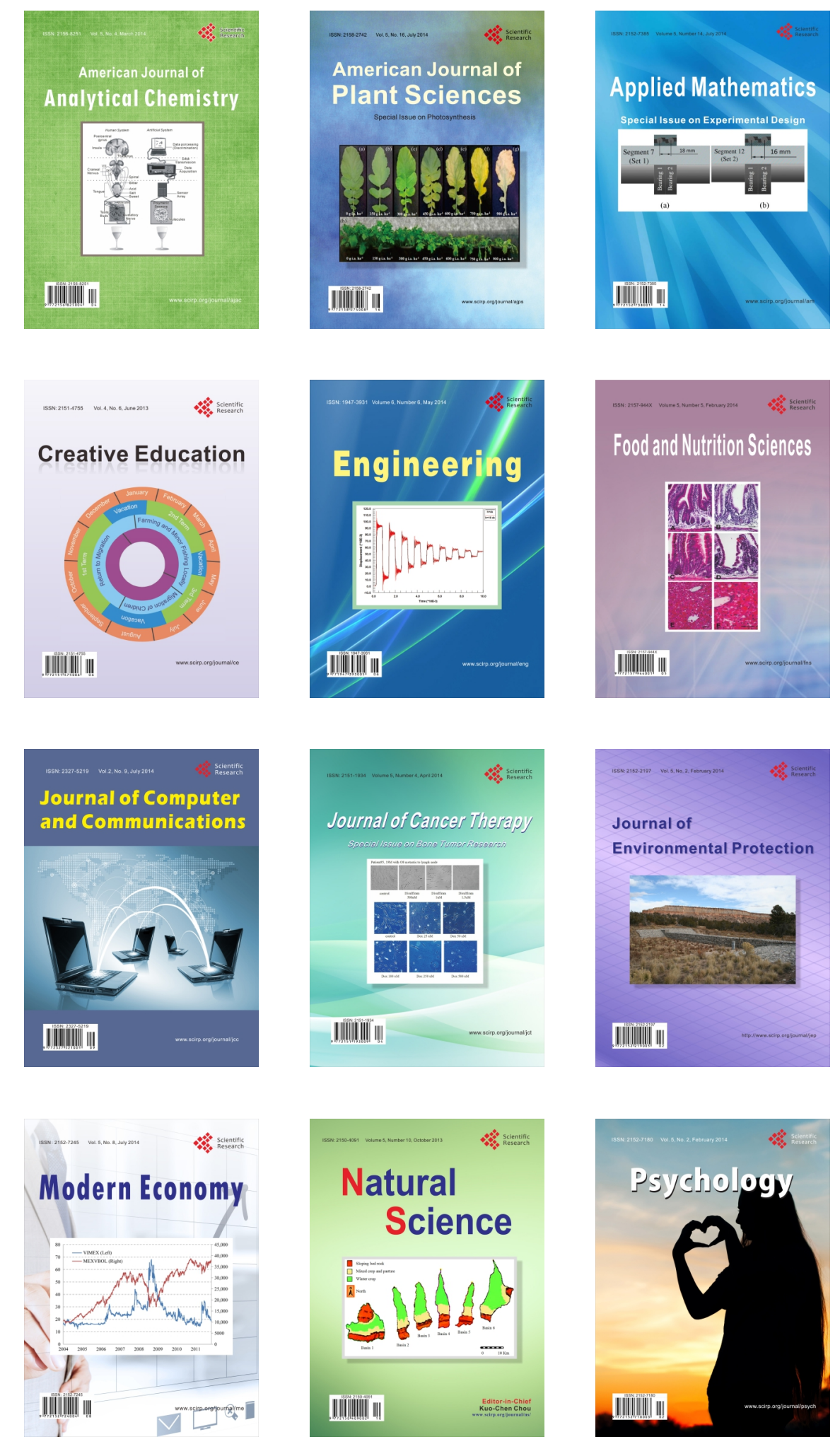